\title{
A SEMIÓTICA VISUAL E A ANÁLISE DO DISCURSO A PARTIR DE UMA IMAGEM SINCRÉTICA EM PINA (2011) DE WIM WENDERS
}

\author{
The visual semiotics and analysis of speech from an syncretic image in Pina \\ (2011) by Wim Wenders
}
La semiótica visual y análisis de discurso de una imagen sincrética en Pina (2011) de Wim Wenders

\author{
Cristiane do Rocio Wosniak \\ Professora na Universidade Estadual do Paraná \\ cristianewosniak@ufpr.br
}

\section{Resumo}

Este artigo se propõe a investigar as relações de intradiscursividade e de provável interpretação de uma imagem fotográfica utilizada como base para a confecção do cartaz/poster e da capa do DVD do documentário poético contemporâneo, Pina (2011) de Wim Wenders, sob a perspectiva da análise deste discurso. As imagens sincréticas selecionadas podem ser examinadas sob os domínios da semiótica visual e, portanto, fundamentar-se na semiótica greimasiana. No percurso gerativo do sentido irão se determinar os dispositivos que o enunciador estabelece e o enunciatário interpreta a partir dos textos nãoverbais em seus planos de expressão relacionados aos seus planos de conteúdo.

Palavras-chave: semiótica visual; imagem sincrética; discurso.

\begin{abstract}
This article aims to investigate the relationships of intradiscursivity and likely interpretation of a photographic image used as the basis for making the poster and DVD cover of contemporary poetic documentary, Pina (2011) by Wim Wenders, from the perspective of analysis of this speech. The syncretic images selected can be examined from the fields of visual semiotics and therefore grounded in semiotics greimasian. In the sense of generative course will determine which devices and establishes the enunciator enunciatee plays from texts nonverbal expression in their plans related to its plans content.
\end{abstract}

Key words: visual semiotics; syncretic image; speech.

\section{Resumen}

Este artículo tiene como objetivo investigar las relaciónes de intradiscursividad e interpretación probable de una imagen fotográfica utiliza como base para hacer el poster/ cartel y portada del DVD del documental poética contemporánea, Pina (2011) de Wim Wenders, desde la perspectiva de el análisis de este discurso. Las imágenes sincréticas seleccionados se pueden examinar desde los campos de la semiótica visual y por lo tanto a tierra en la semiótica greimasiano. En el sentido, por supuesto generativa determinará qué 
dispositivos y establece el enunciatario enunciador juega a partir de textos de expresión no verbal en sus planes relacionados con su contenido de los planes.

Palabras clave: semiótica visual, imagen sincrética, discurso.

\section{INTRODUÇÃO}

A intenção deste artigo é proceder a uma análise semiótica da imagem fotográfica utilizada como base para a confecção do cartaz/poster e da capa do DVD do documentário poético contemporâneo, Pina (2011) de Wim Wenders ${ }^{1}$, como um discurso em que se relacionam, no percurso gerativo do sentido, os planos da expressão e do conteúdo.

A opção pela teoria semiótica de origem francesa desenvolvida por Algirdas Julien Greimas e pelo grupo de Investigações Sêmio-Linguísticas da Escola de Altos Estudos em Ciências Sociais, deve-se ao fato de que esta escola preocupa-se com a teoria do texto e como neste artigo o enfoque é descritivo, buscou-se em Greimas a afirmação de que a descrição é uma construção. Salienta-se, que não se pretende construir um modelo ontológico por meio da semiótica greimasiana, mas, um simulacro metodológico da produção e da compreensão da significação.

Além de Greimas, destacam-se as contribuições de Louis Trolle Hjelmslev que demonstrou ser possível examinar o plano do conteúdo em separado do plano da expressão, rompendo as barreiras entre o enunciado e a enunciação. Também é oportuno lembrar que o sistema semi-simbólico, base da semiótica plástica desenvolvida por Jean-Marie Floch, irá oferecer condições para avaliar categorias plásticas no plano de expressão e categorias semânticas do plano do conteúdo, identificáveis na imagem fotográfica em questão e, com isto, permitir que se possa ir um pouco além dos referentes discerníveis numa mera descrição de elementos isolados, daí a análise do texto e do contexto. Esta investigação nasce das seguintes questões: como a imagem de uma rocha e uma bailarina em pleno salto/vôo podem sintetizar o intradiscurso dinâmico da dança, impresso no conteúdo do cartaz/pôster e capa do DVD do documentário poético? De que forma e com que meios os elementos constitutivos presentes no texto sincrético trazem à cena a fala/voz do contexto em que se inserem Pina

\footnotetext{
${ }^{1}$ Wim Wenders, nascido em Düsseldorf (1945), é um dos cineastas representantes do `novo cinema alemão` . Alcançou projeção internacional na década de 1980 com filmes como: Tokyo Ga (1985); O Estado das Coisas (1982); Paris, Texas (1984) e Asas do Desejo (1987). No final dos anos 1990, passa a se interessar pelo gênero documentário. Em 2011 dirige o documentário poético Pina, baseado na biografia, legado e obra de Pina Bausch, sua conterrânea, coreógrafa e criadora do Tanztheater Wuppertal, e que faleceu durante as filmagens.
} 
Bausch (voz intradiscursiva) e Wim Wenders (elemento enunciador/diretor)? Poderia uma imagem estática dançar/discursar/articular significados?

É preciso acrescentar que toda e qualquer articulação de linguagem se constitui numa espécie de discurso. O desafio da análise do intradiscurso, nesta investigação, portanto, é desvendar a interpretação subjetiva e afetiva/sensível, trabalhando-a como foco principal do processo de construção de sentido, lembrando que não há significado em si, mas uma interrelação de quem fala, para quem se fala e dos lugares simbólicos desta fala.

\section{O TEXTO NÃO VERBAL COMO ENUNCIADO INSTÁVEL E IMPREVISÍVEL}

A semiótica pode ser definida como a teoria geral do texto e da significação. Segundo Diana Luz Pessoa de Barros (1997, p. 7-8), “a semiótica procura descrever e explicar o que o texto diz e como ele faz para dizer o que diz". Para a autora, um texto pode ser definido por duas formas que se complementam, ou seja, como objeto de significação onde se procede à análise estrutural ou interna do texto ou como objeto de comunicação entre sujeitos, onde se insere entre os objetos culturais de uma sociedade, e, deste modo, sendo determinado por formações ideológicas específicas. Neste último caso, o texto precisa ser examinado em relação ao contexto sócio-histórico que o envolve e relacionar-se também com o perfil do destinatário desta recepção, que em última instância irá lhe atribuir este ou aquele sentido a depender de seu repertório ${ }^{2}$, num processo de codificação/decodificação ${ }^{3}$.

Esta investigação apresenta a semiótica como uma teoria em movimento e neste sentido ela dialoga com a dança, matéria seminal investida na configuração da imagem a ser analisada. Recentemente, percebe-se que a semiótica ainda tem enfatizado os estudos sobre a paixão, tensividade, corpo e sensorialidade e mais uma vez, os percursos entre a dança e a semiótica são atravessados por redes mútuas de produção e sentido.

\footnotetext{
${ }^{2}$ É oportuna a observação de Décio Pignatari (2002) em relação ao repertório. Afirma o autor que, para que haja comunicação, de forma efetiva, deve-se pressupor a existência de um repertório [e de códigos em comum] entre transmissor (enunciador) e receptor (destinatário). No sentido mais amplo, Pignatari alega que repertório referese à soma de experiências e conhecimentos codificados de uma pessoa ou grupo.

${ }^{3}$ Cabe salientar que Stuart Hall, um dos fundadores do Centre for Contemporary Cultural Studies, a partir de seus estudos em Ciências Sociais, inscreve em sua obra Da Diáspora: identidades e mediações culturais (2003), um capítulo inteiro a elucidar os fatores inerentes ao processo de codificação/decodificação. Afirma o autor que o discurso/texto "uma vez produzido, deve ser traduzido - transformado de novo - em práticas sociais para que o circuito [codificação/decodificacão] ao mesmo tempo se complete e produza efeitos. Se nenhum `sentido`é apreendido não pode haver 'consumo`. Se o sentido [do texto/discurso] não é articulado em prática, ele não tem efeito" (HALL, 2003, p. 388).
} 
Considerado como texto persuasivo, e, portanto, com uma proposição de afetividade, o cartaz/poster fílmico e a capa do DVD do documentário, são feitos para a divulgação massiva, como recurso publicitário, cuja materialidade - ainda que se refira em primeira instância à imaterialidade do gesto fugaz da dança - deve significar.

É o autor Claude Zilberberg (2001) que menciona a dupla grandesa a ser aplicada no percurso de análise na produção de sentidos do texto não verbal: a tensividade como lugar imaginário em que a intensividade (explorando os estados da alma, da afetividade, do sensível) e a extensividade (o estado das coisas, o inteligível) se unem uma a outra na produção de sentido, como uma espécie de rede ou amálgama. É desta forma que o sentido textual deverá ser afetado, em tensionamento constante, rede de oposições, (des)equilíbrios (equi)distantes, promovendo a imprevisibilidade de efeitos de leitura a depender da trajetória escolhida para a análise do texto, o que gera um ritmo, uma espécie de oscilação tensiva. E quem regularia os efeitos de alternância nesta instância analítica? Segundo Zilberberg é "o próprio eu em posição de sujeito enunciador" (ZILBERBERG, 1988, p. 104).

E retornando à questão do texto, Greimas o descreve como a junção do plano do conteúdo com o plano da expressão:

considerado como enunciado, texto opõe-se a discurso, conforme a substância de expressão - gráfica ou fônica - utilizada para a manifestação do processo linguístico [...] O texto uma vez manifestado, assumirá a forma de uma representação semântica do discurso. (GREIMAS,1979, p. 460).

Em última instância, o texto basta-se a si mesmo. Para a análise do nível fundamental do texto, em seu processo inicial de geração de sentido, observa-se a necessidade de opor termos/formas semânticas com o objetivo de identificar a elementaridade de seu sentido geral.

Na sua obra Elementos da análise do discurso, José Luiz Fiorin (2006) explica os modos e procedimentos para se opor termos e valores que devem necessariamente pertencer a domínios similares e possuir nexos de origem. Assim, justifica-se, por exemplo, as oposições semânticas fluidez/fixidez; solo/ar; salto/aterramento; líquido/sólido; humano/mineral, dança/antidança, que serão coejadas no modelo analítico desenvolvido neste artigo.

Além da oposição semântica é preciso se ater, também, na análise da intradiscursividade do texto, no que Greimas e Courtés (1979) denominam de traços eufóricos (aspecto de positividade-euforia) em oposição aos traços disfóricos (aspecto de negatividadedisforia) dos elementos do todo. Estas marcas positivas versus negativas podem ser definidas pelo/no processo da análise da imagem sincrética, na geração de valores abstratos. 
A imagem fotográfica que serve de base para a elaboração do cartaz/poster fílmico e da capa do DVD, é construída de forma bidimensional ou planar, é um objeto significante, e como tal, faz parte de um sistema semiótico, passível de ser analisado, e, portanto, verbalizado ou nomeado:

A verbalização da mensagem visual manifesta processos de escolhas perceptivas e de reconhecimento que presidem sua interpretação. Essa passagem do percebido ao nomeado, essa transposição da fronteira que separa o visual do verbal é determinante nos dois sentidos. (JOLY, 2003, p. 72-73).

Como objeto significante a ser analisado, a fotografia possui diversos componentes com suas significações específicas e que se articulam uma às outras para produzir a mensagem global.

É o autor Roland Barthes, em seu texto A Retórica da Imagem (1964), quem faz um alerta, observando que a imagem não pode ser confundida com analogia, não sendo apenas constituída do signo icônico ou figurativo. Para o autor os materiais são: o linguístico, o icônico codificado e o icônico não codificado. Em Joly, percebe-se que, num estudo das teorias de Barthes, a autora afirma:

dentro da mensagem visual, vamos distinguir os signos figurativos ou icônicos, que, de modo codificado, dão uma impressão de semelhança com a realidade jogando com a analogia perceptiva... Vamos designar com o termo signos plásticos os componentes propriamente plásticos da imagem, como a cor, as formas, a composição e a textura. Os signos icônicos e os signos plásticos são então considerados como signos visuais ao mesmo tempo distintos e complementares. (JOLY, 2003, p. 75-76).

A partir dos postulados de Barthes é possível compreender a evolução do conceito de ampliação da retórica da linguagem verbal rumo a uma retórica geral, aplicável a todos os tipos de linguagens. Cabe salientar que Floch (1985) faz uma distinção, ao analisar a obra de Barthes, afirmando existir dois modos do sincretizar um texto: um sincretismo paradigmático e um sintagmático. É no segundo aspecto que o enfoque desta investigação recai, no lugar aonde torna-se possível inferir o conceito de intertextualidade ${ }^{4}$ ou o uso de um texto

\footnotetext{
${ }^{4} \mathrm{O}$ termo intertextualidade foi creditado originalmente a Julia Kristeva e apoia-se na tradição dos estudos estruturalistas russos, fundamentalmente, a partir de Roman Jakobson e acima de tudo em Mikhail Bakhtin que trabalham com a noção de interações entre estruturas (campo social, histórico, contextual). A inserção de um texto sobre o outro, ou o escalonamento de vozes dialógicas, proposto por Bakhtin, conduz Kristeva à noção de intertextualidade como fundamento operacional em que se assimilam vários textos, a partir do apoio de um texto centralizador, que deterá o sentido principal. Um novo texto ancorado no(s) texto(s) centralizador(es) está em constante atualização e num percurso interpretativo aberto e dialógico, por meio da geração de sentidos a partir
} 
centralizador (coreografia/fotografia de Pina Bausch) para ser inserido (citação por alusão ou estilização) nos outros textos (cartaz/pôster e capa do DVD) do documentário Pina, por exemplo, produzindo um novo sentido, uma forma de expressão atualizada.

Como textos sincréticos, o cartaz/pôster e a capa do DVD do documentário Pina utiliza mais de um recurso de expressão: a visual e a verbal. Portanto, justifica-se examinar atentamente a imagem fotográfica que irá embasar a criação intradiscursiva dos textos secundários e como eles respondem à imagem primária ou na expressão de Kristeva (1974), centralizadora.

Segundo Mikhail Bakhtin (1984) todo o texto responde a textos anteriores e assim sucessivamente. Estas vozes dialógicas desvendadas no interior de um texto supõem a existência imbricada de uma intradiscursividade por aderências alusivas de possibilidades. De acordo com este teórico, as vozes "não podem ser reduzidas nem às relações lógicas, nem às relações psicológicas, nem às relações naturais ou mecânicas. Elas constituem uma classe específica de relações entre sentidos [...] por trás dos quais estão os sujeitos discursivos" (BRAIT, 2003, p. 25). É por isso, que se pode afirmar que a compreensão de um enunciado neste caso uma imagem sincrética - é sempre dialógica, pois implica um enunciador, um sujeito enunciatário, no interior do enunciado e um terceiro elemento actante, o destinatário, que necessita penetrar no enunciado para atribuir-lhe sentido(s). Esta dinamicidade interativa impressa no processo de codificação/decodificação textual é o que Bakthin (1988) denomina dialogismo ou polifonia e Kristeva, intertextualidade, e, este ato provoca uma tensão dialética na elucidação do discurso/texto, que embora tenha sido pensado e proposto por Bakhtin em relação direta com a literatura, permite-se, ultrapassar e borrar fronteiras, ampliando e atualizando seu campo de atuação/aplicação também para textos imagéticos e/ou sincréticos.

\section{3 (COM)TEXTO SINCRÉTICO: A DANÇA, A FOTOGRAFIA E O PÔSTER/CAPA DO DVD}

Antes de se tornar um cartaz/poster/capa de DVD, a imagem fotográfica, foco inicial da análise neste artigo, existe enquanto processo intertextual/indicial da obra coreográfica de Pina Bausch ${ }^{5}$, intitulada Vollmond (2006) ${ }^{6}$.

de relações contextuais, intertextuais e hipertextuais. Afirma Kristeva (1974), que todo o texto se constrói a partir de um mosaico de citações [advindas de outros textos].

5 Pina Bausch trabalha a partir do conceito de tanztheater. Segundo Vogel (2000), Servos (1984) e Schmidt (1992), neste processo, a fusão entre os elementos da dança e do teatro são fundamentais. Seus textos dancísticos são sincréticos, dialógicos e intertextuais. Seu mote criativo é a relação tensiva entre homens e mulheres. A 
Pina Bausch em Vollmond, remete-nos à uma reflexão sobre o espaço e o tempo de representação. Uma imensa rocha paira inerte no canto direito do palco, enquanto bailarinos em ações não linearizadas ou lógicas, dançam e constroem durante o processo, sentidos semióticos, por associações e argumentos gerados a partir do que Greimas (1984) define como processo de debreagem. Tanto o discurso dançante, como o visual, enquanto textos semióticos, não devem ser considerados como um argumento roteirizado e hermético, mas o resultado de uma leitura que se constrói; este processo é interativo e relacional. É preciso interagir em trânsito semiósico com os diálogos corporais propostos pelo desfile de bailarinos, homens e mulheres, ao dançarem num espaço repleto de água, que cai do teto, sobre os intérpretes e sobre a rocha, estática e implacável, inundando o ambiente cênico. Os diálogos dançantes sugerem não uma empatia, mas ao contrário, a sensação de uma incomunicabilidade entre os gêneros, mote recorrente das obras de Bausch. Nesta perspectiva, não apenas homens e mulheres se opoem na cena, mas o próprio movimento rivaliza com a imobilidade da grande rocha. Vida e morte, fluidez e fixidez, duelam constantemente, propondo um jogo incessante na busca de sentidos para a existência da própria dança em seus (des)limites. Nada é verbalizado em cena, mas tudo é dito, por meio dos gestos, dos movimentos e da voz do corpo dançante. Na transposição da cena coreográfica para a imagem fotográfica (ver figura 1) temos a essência, o instante em que o significado preemente deixase capturar. O instantâneo do vôo simbólico da intérprete feminina em meio a uma profusão de água, contrasta com a imobilidade decisiva e irremediável da rocha, estando ambos os elementos lado a lado na cena. Na elaboração do material publicitário para efeitos de divulgação - cartaz/pôster e capa do DVD - como forma de discurso massivo, a proposição da criação assenta-se na questão da persuasão: qual instância imagética favorecerá o texto/ideia/mensagem/significado de movimento/dança, matéria primeira de que é constituído o documentário poético Pina? De que forma e com que meios poder-se-iam anunciar e

incapacidade de efetivar possíveis conexões comunicacionais. Nesta busca pelas oposições, efeitos contrários e dupla perspectiva, nasce o corolário-chave desta criadora vanguardista alemã: a fragmentação e a repetição do gesto como geradoras da `collage` cênica que propõe em suas obras.

6 Vollmond (trad: Lua Cheia) é uma peça coreográfica de Pina Bausch e que estreia em 2006. Aborda um território fluido (a água abundante caindo como uma tempestade sobre o palco) onde as relações conturbadas entre homens e mulheres ainda é a tônica maior. Desta vez, ocorre mais um obstáculo no campo de forças opostas: uma grande rocha paira soberana num dos cantos do palco enquanto os dançarinos-atores desfilam movimentos acrobátios e desafiam a própia gravidade ao se lençarem em grandes saltos de cima da rocha para o palco coberto literalmente de água. Tanto o cenário de Peter Pabst quanto o projeto de iluminação contribuem para a atmosfera ritualística da obra. A frase de abertura consiste em: 'é noite de lua cheia... É perigoso se embriagar'... 
persuadir o destinatário de que se trata de um texto - representação semântica do discurso apoiado na forma dançante?

A opção, como aponta o suporte imagético sincrético (ver figura 2) foi a imagem da intérprete feminina capturada no instantâneo de movimento (salto) em meio a uma profusão de cor quente (alaranjada) e com a corroboração do discurso verbal - a frase: dance, dance, otherwise we are lost. ${ }^{7}$

Seria este o sentido pretendido como mote do documentário? A dança como resposta, ao menos temporária, para o discurso não verbal, para a expressão do indizível? Seria a dança, por meio das vozes dialógicas de Bausch e Wenders, a voz do texto documental, explicitadas na campanha publicitária para divulgação em massa?

\section{O SIGNIFICANTE NA IMAGEM FOTOGRÁFICA E NO CARTAZ/POSTER - A ROCHA E A BAILARINA}

O texto é a unidade da manifestação. É o lugar em que os diferentes níveis (fundamental, narrativo e discursivo) do agenciamento do sentido se manifestam e se dão a ler. A leitura descritiva da imagem em questão - uma fotografia/acervo do Tanztheater Wuppertal, para divulgação do espetáculo - apresenta uma figura feminina que ocupa a posição da lateral esquerda do enquadramento fotográfico. A referida figura porta um vestido alaranjado, característicos dos personagens femininos bauschianos.

Figura 1: Fotografia da obra Vollmond /2006 - na cena do filme Pina /2001 de Wim Wenders

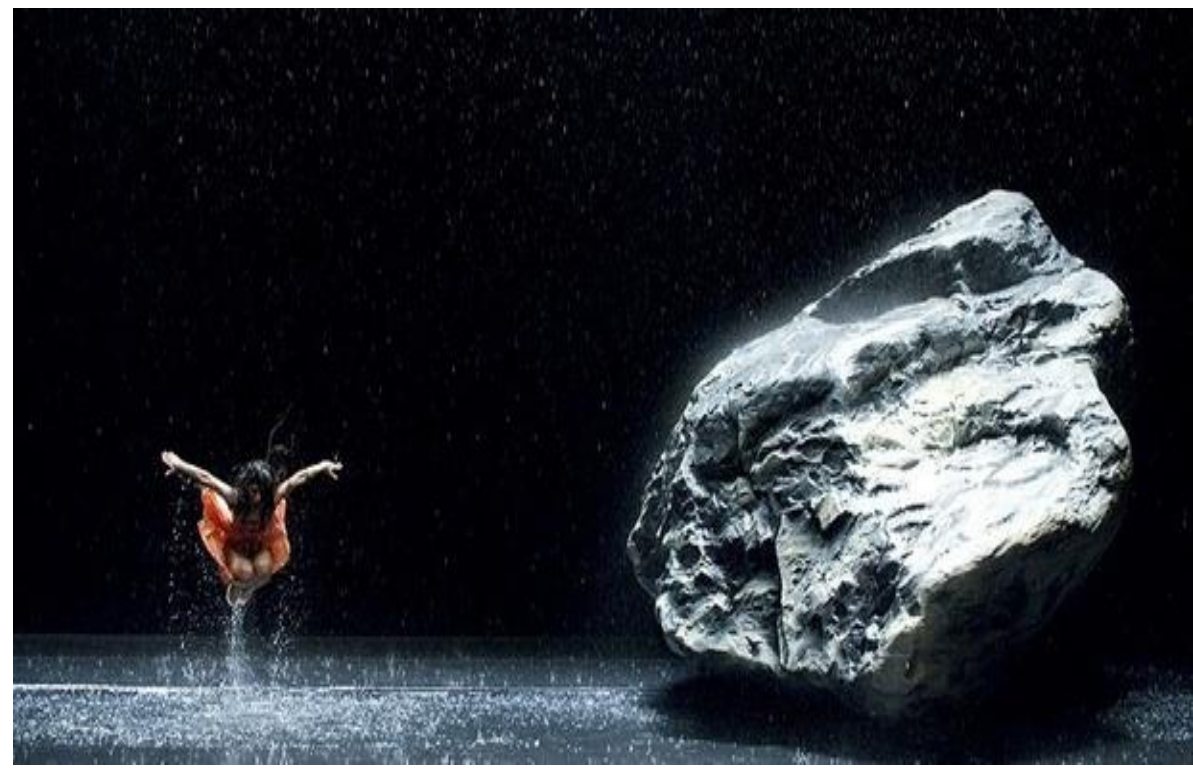

7 Tradução livre: dancem, dancem, do contrário estamos perdidos. 
Fonte: Imagem disponível em: www.kingsroad.it/?p=3490)

O instantâneo capturado pela câmera, focaliza um movimento de salto (ausência de base de suporte/pés em contato com o solo) com os joelhos flexionados, os pés unidos e os braços alongados em abdução, acima do nível da cabeça e mantendo-se as palmas da mão voltadas para baixo. Observa-se que a intérprete calça um par de sapatos brancos e sua cabeça com cabelos negros soltos e fartos, pende para baixo, olhando para o chão. Esta sensação de movimento é corroborada pelos pingos de água que jorram de cima de sua figura, vindos de cima e se espalhando pelo chão. No lado oposto do enquadramento, ou seja, do lado direito, encontra-se inerte, a figura de uma imensa rocha na coloração preta-acinzentada, iluminada por um facho de luz clara o que faz com que sua superfície reflita um intenso brilho. Este elemento possui arestas disformes, angulosas e a luz incidente sobre si, projeta uma espécie de sombra no palco. Sobre um fundo negro, destacam-se apenas os pingos d’água caindo e se esparramando no chão.

Figura 2 - imagem do pôster/capa do DVD de Pina (2011) 


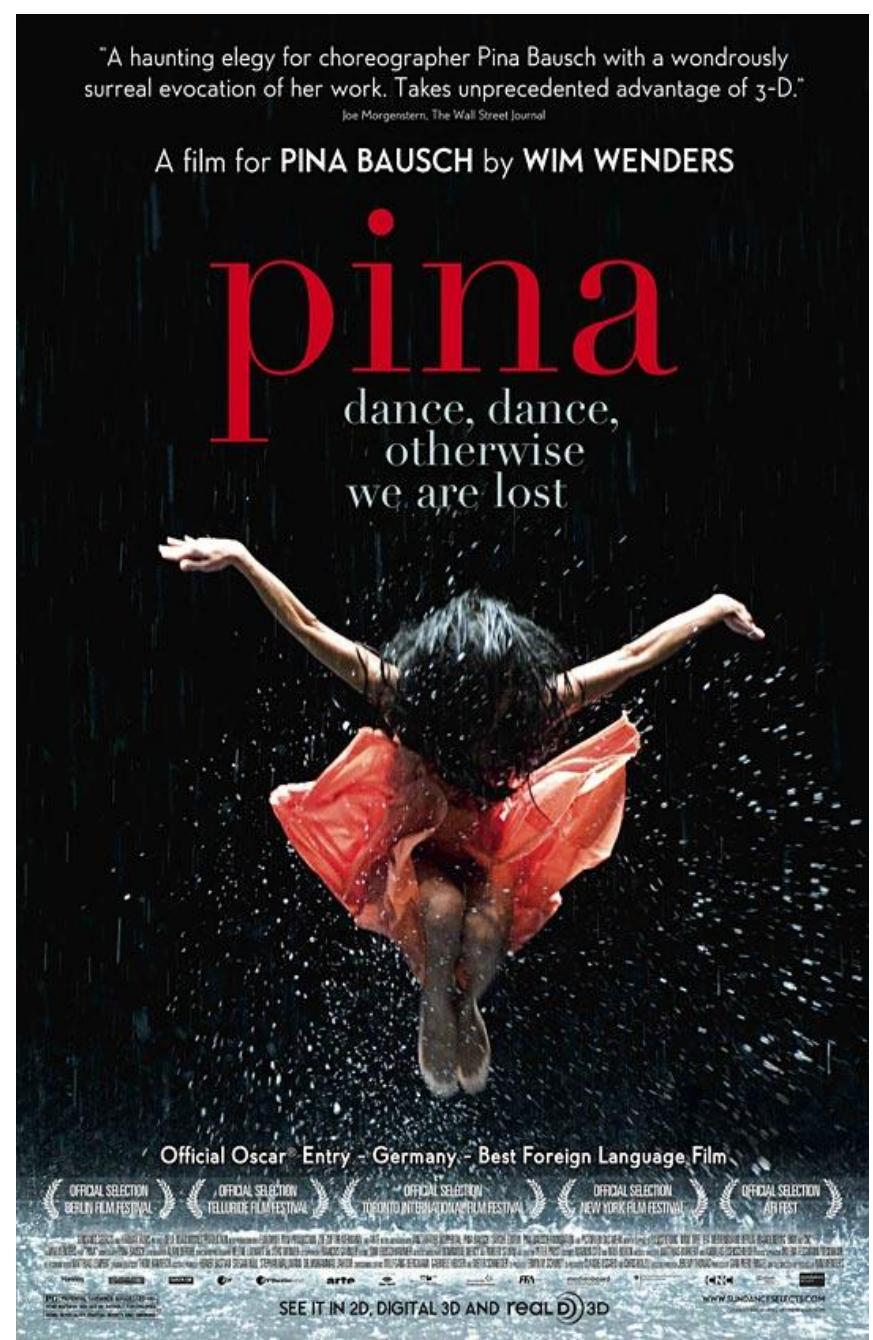

Fonte: imagem disponível em: www.terroirgourmet.com2012/10/pina.homenagem-de-wim-wenders-sobre-avida-de-pina-bausch)

Inicialmente analisando-se o plano de expressão da imagem fotográfica (ver figura 1), sob a perspectiva de Floch (1985), para quem os elementos constituintes de uma mensagem encontram-se no mesmo espaço, no enunciado, podemos verificar as seguintes categorias semi-simbólicas:

- Categoria constitucional cromática - Tonalidades: cor alaranjada (vestido da mulher/bailarina) versus cinzento (rocha) - associando o alaranjado, liberdade, movimento, dia, vida, fluidez, calor, euforia, e o tom cinzento à prisão, imobilidade, noite, morte, fixidez, frio, disforia. Cor branca (sapato/sapatilha da mulher/bailarina) versus negro (sombra da rocha) - associando a cor branca do sapato/sapatilha à resolução da questão simbólica do peso/gravidade, sensação de leveza, etéreo, inocência, alegria, iniciativa, espontaneidade, celebração de vida e a cor negra da sombra da rocha no solo associado tanto à ausência de cor quanto à sua questão simbólica de firmeza, solidez, pesado, malícia, tristeza, inércia, formalidade, 
sobriedade, luto, pesar. Cor `nude`ou bege claro (cor da pele de braços e pernas) versus acinzentado (rocha) - associando a cor bege claro ao humano, vívido, pele, poros, respiração, transpiração, vida, e a cor acinzentada ao mineral rochoso, inerte, solidez, rugosidade, morte.

Cabe salientar que a cor é uma construção de sentido inserida num contexto sociocultural. Em Semiótica Plástica, a autora Ana Claudia Oliveira (2004) afirma que que as cores "agem como codificadoras de mundos" (OLIVEIRA, 2004, p. 119). Apreender o seu sentido é apropriar-se de símbolos construídos culturalmente e portanto, trata-se de um processo comunicacional.

É a partir da proposta elementar do semi-simbolismo de separar a análise do plano de expressão da do plano do conteúdo, e, sem ter a pretensão de esgotar essas possibilidades, que se pretende continuar o processo de elucidação das pistas deixadas pelo texto em suas demais categorias.

- Categorias relacionais eidéticas - Formas - humana (bailarina) X mineral (rocha) referentes aos personagens representantes do Movimento versus Imobilidade; forma da bailarina em vôo (salto/base de suporte ausente) com braços abertos, em expansão na direção cima versus forma do elemento mineralizado e rochoso, anguloso, em retraimento, base sólida e fortificada contra o solo, prostrado ou inerte - referentes à força dos símbolos oposicionais da ação (movimento/nível alto/dança/desequilíbrio) sobre a inação (estabilidade, nível baixo/imobilidade/equilíbrio); forma humana retilínea, alongada, vetorial e verticalizada em direção ao alto (negação da gravidade) versus forma rochosa curvilínea, retraída, horizontalizada em direção ao solo (base estável) referentes ao discurso do movente versus imovente; vida versus morte; risco versus estabilidade; acaso versus previsibilidade; instabilidade versus estabilidade; cima versus baixo; céu versus terra;

- Categorias relacionais topológicas - Orientação: alto (verticalidade) versus baixo (horizontalidade) - a figura humana (bailarina em salto) é percebida como verticalidade/superatividade/potência/vida e a figura do elemento mineral (rocha) como horizontalidade/imobilidade/impotência/morte; lado esquerdo versus lado direito - o elemento na lateral esquerda (bailarina) é percebida como potencialidade de movimento/ação e na lateral direita, atingida por um ângulo de iluminação cênica, o elemento (rocha) é percebido como impotência/inação e portanto inativo na composição dos termos a partir do foco de movimento; Dimensão: alta versus baixa - 
a figura humana (bailarina) é percebida como simbolicamente superior, em relação à dimensão altura (cima/baixo) e a figura do elemento mineral (rocha) como simbolicamente inferior em relação à dimensão altura sem possibilidades de reversão; aberto/expansão versus fechado/retração - a figura humana (bailarina) é percebida como expansiva e dominante em seu posicionamento superior em relação à base de suporte em oposição ao elemento rochoso, contraído em sua posição inferior, em relação à base de suporte.

Relacionando-se as categorias do plano do conteúdo com as do plano da expressão, teríamos os seguintes argumentos sintetizados a partir do Elemento Eufórico versus Elemento Disfórico: ação $\rightarrow$ inação; figura humana/bailarina $\rightarrow$ figura rochosa; ação de vôo/salto $\rightarrow$ aterramento ao solo; verticalidade vetorial $\rightarrow$ horizontalidade; altura/alto/céu $\rightarrow$ largura/baixo/terra; potenciais retilíneos $\rightarrow$ potenciais curvilíneos; cor alaranjada $\rightarrow$ cor acinzentada/preta; cor branca $\rightarrow$ cor acinzentada/preta; sensação de leveza $\rightarrow$ sensação de peso; sensação de expansão $\rightarrow$ sensação de contração; suavidade $\rightarrow$ rugosidade; movimento/dança $\rightarrow$ imobilidade/anti-dança.

\section{ANÁLISE DO DISCURSO - O PERCURSO GERATIVO DO SENTIDO}

Em Teoria Semiótica do Texto, Barros (1990, p. 10-11), afirma que no nível das estruturas fundamentais é preciso determinar a oposição ou as oposições semânticas a partir das quais se constrói o sentido do texto. $\mathrm{Na}$ imagem fotográfica, a categoria semântica fundamental é: o movimento/fluidez/vida/calor/leveza/antigravidade/dança, do instantâneo da intérprete feminina em atitude de pleno vôo/salto, tendo como oposição simbólica a imobilidade/fixidez/morte/frio/peso/gravidade/antidança obtidos pelo caráter da inércia simbolicamente atribuídos a uma rocha. Esta oposição é perceptível de diferentes maneiras: o movimento é representado pelo personagem da bailarina vestida de alaranjado, auxiliada pelo reconhecimento de um movimento/saltado. Numa dupla ação, a bailarina, ao mesmo tempo, que salta e nega a gravidade, mantém sua cabeça voltada para o nível baixo/solo, delegando ao destinatário a certeza de que este gesto/salto em breve retorna ao seu local de origem e torna-se uma potência de movimento (cima/baixo/cima) que se traduz em dança. A Imobilidade é representada pela rocha que, com sua solidez e inércia, emblematiza a fixidez, a incapacidade de geração espontânea de movimento, matéria-prima da dança, logo, em oposição, gera o conceito de antidança. A fluidez e espontaneidade também podem ser 
atribuídas ao elemento água, que torna-se abundante no enquadramento e um elemento adicional à corroboração do discurso do movimento, da dança.

$\mathrm{Na}$ passagem do suporte fotográfico para o cartaz/poster/capa de DVD, metonimicamente, a cena é recortada e o emblema bailarina destaca-se no centro da imagem. A rocha, suprimida, cede lugar ao tema/mensagem principal do documentário poético: a dança. Acima da imagem da intérprete feminina, paira a frase "dance, dance, otherwise we are lost”, confirmando a retórica de que somente pela dança chega-se à compreensão do(s) significado(s) para os quais as palavras não são suficientes - mote do documentário poético esta frase abre e encerra o referido filme. $\mathrm{O}$ encontro dos sentidos sensíveis, poéticos e estéticos se dá pela(na) dança, parecem propor Pina Bausch e Wim Wenders. Esta proposição poderia se ancorar em Greimas, mais especificamente, em sua obra Da Imperfeição, na leitura ou decodificação orientada para "a apreensão de determinada forma de presença sensível do sentido" (GREIMAS, 2002, p. 137).

Prosseguindo com a análise, percebe-se que as categorias fundamentais são determinadas como positivas ou eufóricas e as negativas como disfóricas. No texto visual fotográfico, a rocha acinzentada e a sombra negra projetada são disfóricas e associadas à imanência da imobilidade, da fixidez, do peso rígido e da incapacidade de mudança de lugar, da inação. As representações da intérprete-bailarina e do elemento água em abundância, por sua vez, são associados ao triunfo do fluxo do movimento, da celebração da vida, da dança, da capacidade de deslocar entre-lugares, de propor o inusitado, de causar mudanças e ações daí decorrentes.

No nível das estruturas narrativas, observa-se a oposição de valores, ou seja, o sujeito (bailarina em pleno instante de vôo/salto) nega o efeito do peso, da imobilidade, da gravidade, do sistema, das regras, das normas, impostas pelo anti-sujeito (representação da fixidez da rocha). O sujeito para cumprir o acordo tácito de mobilidade, poeticidade, leveza, dança, produção de calor pelo movimento, combate a inércia do anti-sujeito e de seu empenho voltado para a inação, promovendo um salto, uma negação da gravidade, um instante de pura rebeldia e enfrentamento do sistema vigente, da frieza, da antidança. O compromisso com o discurso do movimento, da dança, do dançar, dançar, pois do contrário estaremos perdidos condenados à fixidez - é mantido e reforçado pela presença da água abundante (fluxo contínuo similar aos movimentos em ação dançante). 
A presença da figura da bailarina (sujeito dançante) e da rocha (antisujeito dançante) sugere que se tratam-se de imagens simbólicas culturalmente reconhecidas e, assim, a imagem sincretiza sujeitos de fazeres contrários.

A última etapa do percurso gerativo do sentido é o nível das estruturas discursivas. Em primeiro lugar, na imagem sincrética do cartaz/poster e capa do DVD do documentário poético Pina, projeta-se uma espécie de narrador em $3^{\mathrm{a}}$ pessoa: trata-se do discurso de Pina Bausch e da ideologia de um sistema denominado tanztheater, por meio do qual a dança torna-se uma espécie de voz do corpo em movimento, com significantes e códigos próprios, capaz de exprimir o discurso do indizível pelas linguagens híbridas da dança e do teatro. $\mathrm{O}$ sujeito (bailarina) torna-se mediadora, a portadora da mensagem "dance, dance, otherwise we are lost". Ela aponta e sugere o caminho/exemplo do movimento, como acordo para se encontrar os significados de possíveis mensagens, por meio da dança. É o que se considera um ato comunicativo, significando que, neste caso, deve-se "inserir o corpo no jogo comunicacional, diante do qual ele deve saber falar e ser compreendido" (ROCHA, 2000, p. 151).

Determina-se o sujeito da negação do movimento (rocha estática) como mensageiro e também portador de um outro discurso: o da antidança, da imobilidade, da resistência à ação, à inovação, à busca da expressão por outras vias que não a da conformidade com as regras imutáveis.

Para se perceber as estratégias da enunciação, deve-se buscar as pistas no enunciado. Por meio do processo que na semiótica greimasiana denomina-se embreagem/debreagem, procuramos as marcas que nos possibilitam o entendimento do processo. Isto acontece pela reiteração no texto. Assim, observa-se que no próprio enunciado tem-se quatro sujeitos enunciadores que desembreiam o sujeito discursivo, pois se pressupõe no enunciado um $E u$ para propor o movimento/dançar (mediação), um outro $E u$, ou melhor um anti-Eu para originalmente negar o movimento/pairar inerte na imagem e um Você a quem é dirigida a mútua enunciação. Entretanto, observa-se uma espécie de auxílio ou reforço da mensagem do sujeito, que se faz pela enunciação da água escorrendo/caindo em abundância numa alusão ao fluxo incessante de movimento.

Na passagem do suporte fotográfico para o cartaz/poster/capa do DVD, tem-se ainda o reforço verbal da frase "dance, dance, otherwise we are lost", contribuindo para a enunciação do $E u$ sujeito principal. Assim, os sujeitos eufóricos oferecem a dissolução da imobilidade, pela ação/movimento/calor/salto, ao propor a dança como possibilidade contra a perdição de 
sentidos apreendidos; o antisujeito disfórico oferece a imbilidade e a inércia como conformidade, frieza e passividade. Você, o sujeito a quem a mensagem é dirigida, tem a opção do livre arbítrio: querer ou não querer o movimento, o fluxo, o calor, a dança como mensagem discursiva (a mensagem principal). O sujeito pressuposto que assume a dança, por sua atitude de combate, atividade, resistência a negação da gravidade e potência sobre a imobilidade e inércia, mantendo ativa postura/salto contra a gravidade, caracteriza o procedimento de persuasão e da apresentação da motivação central - a dança - como propulsora de um discurso poético, contra a passividade, imobilidade, frieza e conformismo vicioso.

O enunciador da imagem fotográfica e do cartaz/poster/capa do DVD ao instalar as projeções da enunciação, em pessoa, espaço e tempo, cria efeitos de atualidade e de verdade, baseado em fatos ocorridos em um momento de referência pretérita e alhures, como os motes e mensagem implícitas nas obras coreográficas de Pina Bausch e tematizadas no documentário poético Pina (2011). Assim, apresenta-se o simulacro discursivo do enunciador e enunciatário explícitos.

\section{O ENUNCIADO E A ENUNCIAÇÃO: ARTICULAÇÃO DE MENSAGENS EX(IN)PLÍCITAS}

Ao analisar os textos visuais sincréticos (fotografia e cartaz/poster do documentário poético) como um discurso poético, porém persuasivo, parte-se do pressuposto de que algo será comunicado a alguém de alguma forma e com alguma intenção.

Cabe lembrar o esquema básico de comunicação proposto por Roman Jakobson (1969), que prioriza a articulação da mensagem e seus fatores na dimensão horizontal/sentido linear: destinador $\rightarrow$ destinatário. Esta tendência limitante do esquema de Jakobson foi questionada por Greimas e Courtés, cuja semiótica considera que "a comunicação se aproxima muito mais de um fazer-crer (persuasão) e de um fazer-fazer (manipulação) do que de um fazer-saber, pressuposto fundante do esquema de comunicação tradicional." (NASCIMENTO, 2002, p. 63).

Neste sentido, Jacques Fontanille irá propor um novo esquema onde a comunicação abandona a centralização de um sentido linear/horizontal para implicar-se na enunciação e no enunciado por ela produzida. Afirma o autor: "em cada nível, a análise toma em consideração a heterogeneidade dos dados aos quais lhe cabe prestar contas, e ela converte este conjunto heterogêneo em conjunto significante.” (FONTANILLE, 2006, p. 34). 
Neste conjunto significante ou jogo enunciativo, além do texto (enunciado) há de se pressupor o contexto (enunciação). Assim, segundo Nascimento, "descrever a significação de um enunciado é descrever sua enunciação, ou seja, propor uma representação do surgimento deste enunciado no contexto dado.” (op. cit., p. 66). Na representação esquemática de Fontanille, pode-se verificar os pressupostos desta afirmação:

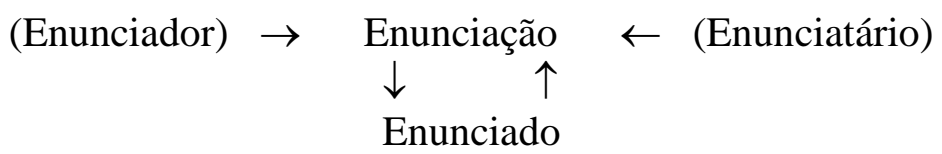

Ainda em Nascimento (op. cit. p. 67-68), observamos a explicação do funcionamento deste esquema, ou seja, do ato enunciativo, processo ativo que ocorre não só no sentido horizontal, mas também pressupõe a verticalidade: o eixo da comunicação que a semiótica greimasiana atribui um valor sintagmático, articula no sentido horizontal (destinador/emissor e destinatário/receptor). Já o eixo da produção a que se atribui um valor paradigmático, articula no sentido vertical (sujeito/da enunciação e objeto/enunciado). O ato de leitura e construção de sentido ou significado ocorre em ambos os sentidos (cima/baixo e baixo/cima) no eixo vertical segundo o processo descrito:

A passagem da enunciação para o enunciado se efetua graças a um procedimento denominado desembreagem que permite que se projete para fora desta instância tanto os actantes do enunciado quanto as coordenadas espaço-temporais (a pessoa, o espaço e o tempo ou em termos semióticos, o eu, o aqui e o agora) [...] Mas como o que nos é dado é sempre o enunciado, nunca a enunciação - sempre pressuposta - o caminho que se faz inicialmente é inverso àquele que se apresentou acima e é levado a efeito pelo mecanismo da embreagem. Esta permite que, a partir do enunciado dado, se tenha acesso, por pressuposição, ao lugar imaginário-transcedental da enunciação. (op. cit., 67-68).

As leituras abstratas do enunciado caracterizam-se pela oposição relacional de fatores que separam, na imagem fotográfica, a Imobilidade/Traço Disfórico versus Mobilidade/Traço Eufórico:

- traço temporal: inércia versus salto/movimento;

- traços espaciais: nível baixo/terra versus nível alto/céu; horizontalidade da figura rochosa/anulação versus verticalidade da figura feminina/força; lateral direita da foto = figura estática/rocha versus lateral esquerda = figura em movimento/bailarina;

- traços dimensionais: rocha $=$ grande/larga/baixa versus bailarina $=$ pequena/comprida/alta; 
- traços visuais: rocha $=$ assimetria/desequilíbrio formal versus bailarina $=$ simetria/equilíbrio formal; linhas angulosas/arestas/curvas/rugosidade versus linhas retas suavizadas;

- $\quad$ traços de tonalidade: rocha $=$ preto/acinzentado/trevas na extremidade inferior/sombra versus bailarina $=$ alaranjado/vestido de cor quente e vibrante; negro/sombra versus branco/sapatos; acinzentado/frieza/morte versus alaranjado/vestido/calor/vida; negro/sombra versus nude/bege claro/tom da pele da figura feminina;

- traços táteis: rocha = textura áspera/rugosidade/frio versus bailarina $=$ textura lisa/suave/calor.

\section{O SIGNIFICADO NA IMAGEM FOTOGRÁFICA E NO CARTAZ/POSTER}

O processo de análise dos suportes fotográfico, cartaz/poster e capa do DVD, pode fornecer pistas para elucidar os possíveis modos com os quais o documentário poético articula e dialoga com as oposições movimento/imobilidade, leveza/peso, ação/inação, levando-se em consideração o diálogo travado de forma persuasiva com o espectador/consumidor do texto documental.

Wim Wenders e Pina Bausch decidiram realizar um trabalho colaborativo e em 2008 chegaram ao projeto do que se tornaria o documentário poético Pina (2011). Bausch, que não pretendia que Wenders abordasse sua biografia, mas se concentrasse em sua obra, seu método de criação e acima de tudo no Tanztheater Wuppertal, seleciona, dentre sua vasta produção, quatro obras emblemáticas que poderiam sintetizar seu credo artístico e por meio as quais os intérpretes de sua companhia poderiam desfilar os movimentos e ações dançantes que simbolizariam a dialética da tensividade constante de suas composições. Entretanto, a coreógrafa e diretora falece em 2009 e o documentário é finalizado por Wenders como uma espécie de tributo e reverência à sua conterrânea e artista vanguardista.

A importância dada aos objetos cênicos nas obras de Bausch são uma realidade estética. Os dançarinos se opõem, chocam, transcendem, manipulam, e atuam com os adereços, numa espécie de parceria consentida. Trabalha-se no nível das ambiguidades e das subjetividades. Como relembra Fábio Cypriano (2005) "a dança-teatro apresenta, ao mesmo tempo, os sinais positivos e negativos [eufóricos e disfóricos?] das situações apresentadas. Isto permite que o espectador [destinatário] tome uma decisão, se assim o quiser" (CYPRIANO, 2005, p. 114). 
O trecho de Vollmond (2006), última obra concebida por Pina Bausch, é a obra que finaliza o documentário e nesta perpectiva, a dança parece propor uma síntese do coroláriochave bauschiano: oposição entre homens e mulheres, transcendência do gesto, por meio da repetição e fragmentação do movimento, significados simbólicos e narrativas enviesadas além da negação da lógica da linearidade, ocupando-se o palco plenamente, com recursos tais como o fluxo contínuo de água que cai do teto inundando o palco e a iluminação simbólica sobre a imensa rocha inerte, numa alusão à Lua Cheia/Vollmond e os efeitos inusitados causados pela presença desta forma simbólica, que, embora estática, é o fio condutor que gera a tensão e a premissa entre os intérpretes, que são impelidos ao movimento, ao jogo coreográfico. A dança ocupa o espaço de representação em conversa dialógica com o obstáculo que se apresenta in locu. Salienta-se a importância, dada por Pina Bausch, à interpretação aberta de seu público, evitando, sempre que possível, direcionamentos e enfoques restritivos em seus textos de dança, o que pode-se verificar em entrevista concedida à Cypriano (1998): “deve-se estar livre e confiar em si próprio, no que se está sentindo quando se vê a peça. E quando se vê mais vezes, ela muda, da mesma forma que mudamos nossos sentimentos [...] Eu acho que uma peça deve ser tão aberta para mim quanto para os outros para que cada um possa construir sua própria peça nela.” (op. cit., p. 129).

Os suportes para divulgação do documentário - cartaz/poster e capa do DVD, apresentam em sua estrutura sincrética o personagem central, identificado como a bailarina de Wuppertal, a própria (encarn)ação ideológica de Pina Bausch/Wuppertal, devido à presença dos símbolos icônicos do vestido alaranjado (figurino e cor recorrentes nas obras bauschianas), no instante do salto (o fator imprevisível) além da presença dos pingos d'água, (manifestação celebrada em outras obras da diretora, tal como em sua obra Arien /1979). A estilização desta figura, remete à identificação do conteúdo a ser narrado/falado no documentário: o acordo tácito afirma tratar-se da discursivização da dança.

Segundo Bertrand (1985, p. 412) a estilização pode ser polêmica ou contratual. E ainda acrescenta: "a estilização é a reprodução do conjunto dos procedimentos do discurso de outrem, isto é, do estilo de outrem." Fica claro que os signos figurativos estão na imagem por algo mais que eles próprios, estão presentes pelas conotações que evocam. Na realidade, afirma Joly (2003, p. 104-105) este tipo de representação é eminentemente sinedótico ou metonímico, isto é "só vemos partes de elementos que ali estão para designar o todo por contiguidade...”. Pode-se descrever estes elementos associativos da seguinte maneira: 
- significante icônico (1) = figura feminina com vestido alaranjado em atitude de salto (ausência da base de suporte em contato com o chão). Significados de $1^{\circ}$ nível: mulher com traje feminino saltando. Conotações de $2^{\circ}$ nível: bailarina/catarse/dança/intérprete do Wuppertal Tanztheater;

- $\quad$ significante icônico (2) = figura feminina saltando com sapatilhas brancas e braços abertos ao alto. Significados de $1^{\mathrm{o}}$ nível: mulher saltando espontaneamente com caçado branco. Contações de $2^{\circ}$ nível: bailarina/dança/intérprete do Wuppertal Tanztheater;

- significante icônico (3) = figura feminina saltando. Significados de $1^{\circ}$ nível: mulher exuberante e espontânea. Conotações de $2^{\circ}$ nível: movimento/fluidez/negação da gravidade/imprevisibilidade/contentamento/geração de calor/leveza;

- significante icônico (4) = rocha acinzentada com superfície rugosa, ângulos e arestas. Significados de $1^{\circ}$ nível: estrutura mineral rochosa. Contações de $2^{\circ}$ nível: elemento cênico estilizado/obstáculo/imobilidade/fixidez/peso/ação da gravidade/ação de previsibilidade/lua cheia/Vollmond;

- $\quad$ significante icônico (5) = elemento água/pingos, cascatas, inundação do chão/palco. Significados de $1^{\circ}$ nível: chuva. Conotações de $2^{\circ}$ nível: elemento cênico estilizado/frescor/fluidez/movimento contínuo;

- significante icônico (6) = cabelos femininos soltos e molhados. Significados de $1^{\mathrm{o}}$ nível: cabelos femininos molhados. Conotações de $2^{\circ}$ nível: elemento de caracterização cênica/espontaneidade/liberdade/fluidez.

Sob o ponto de vista semântico, as imagens analisadas mostram a vitória ou superioridade eufórica do Movimento (bailarina em atitude de salto espontâneo) sobre a Imobilidade disfórica (rocha inerte) sob a oposição do acordo tácito do texto/discurso Dança. O sujeito da enunciação ao estabelecer o contrato entre enunciador e enunciatário faz um comunicado visual que deve levar o enunciatário a um dever-fazer (movimentar, saltar, dançar), a um querer não fazer (imobilizar, aterrar, ficar) e a um dever-saber (o que o ato da dança propõe/espontaneidade, alegria, calor), em outras palavras: dever fazer o Movimento, a Dança a conversão e a crença na superação da gravidade, dos obstáculos, da inércia, da imobilidade conceitual, querer não fazer a permanência estática, descrente e fria da rocha em sua eterna passividade e atitude de antidança. 


\section{CONSIDERAÇÕES FINAIS}

Por meio da análise de um texto não verbal e sincrético, sob a perspectiva da semiótica visual greimasiana, associada ao percurso gerativo de sentido de um discurso, percebe-se que a imagem é um meio de expressão e de comunicação que nos vincula às tradições e repertórios mais antigos e, portanto, enraizados historicamente em nossa cultura. Para sua compreensão e leitura, necessita-se levar em conta alguns contextos da comunicação, da historicidade de sua interpretação e de suas especificidades culturais. Como discurso poético e estético, as imagens sincréticas analisadas produzem uma espécie de ficção, um percurso subjetivo de análise e interpretação. A própria estrutura da mensagem orienta-se numa determinada organização de signos conferindo-lhe a identidade de um discurso persuasivo, isto é, com a intenção ou função de seduzir o destinatário da mensagem e afirmar-lhe com convicção, tratar-se de um discurso poético fundamentado na Dança. Neste caso, o canal, o veículo ou o medium cartaz/poster ou capa do DVD do documentário poético Pina impõe um perfil conativo ou apelativo a esta linguagem, centralizando-a no destinatário.

Se a mensagem contém sentido, este tem de ser apreendido e lido por seu destinatário, por seu leitor/espectador que em sua relação com o enunciado ou neste caso, um texto visual sincrético, mobiliza diversos códigos, alguns quase universais (percepção), outros estruturados socialmente (analogia) e outros ainda ancorados no contexto sociocultural.

Portanto o que se pretendeu demonstrar por meio de uma análise semiótica visual, resume-se ao fato de que no percurso gerativo do sentido ou significado de uma mensagem, muitas vezes o visual determina uma contaminação do verbal pelo icônico. O conhecimento dos mecanismos intradiscursivos na determinação de prováveis sentidos, neste caso, pode auxiliar no processo de leitura, codificação/decodificação de textos visuais e sincréticos.

Assim sendo, este artigo evidencia um provável percurso analítico, uma possível leitura semiótica, mas que não se pretende esgotada, visto que, na leitura de obras poéticas, estéticas e abertas, as possibilidades são dialogicamente infinitas.

\section{REFERÊNCIAS}

AUMONT, Joly. A imagem. Trad. Estela dos Santos Abreu e Cláudio Santoro. Campinas: Papirus, 2004.

BAKHTINE, Mikhail. Esthétique de la création verbale. Trad. Alfreda Aucouturier. Paris: Gallimard, 1984. 
BAKHTIN, Mikhail. Questões de literatura e de estética: a teoria do romance. Trad. Aurora Bernardini e outros. São Paulo: UNESP/Hucitec, 1988.

BARROS, Diana Luz Pessoa de. Teoria semiótica do texto. São Paulo: Ática, 1990.

BARROS, Diana Luz Pessoa de \& FIORIN, José Luiz (orgs.). Dialogismo, polifonia, intertextualidade. São Paulo: EDUSP, 1999.

BRAIT, Beth. As vozes bakhtianas e o diálogo inconcluso. In: BARROS, Diana Luz Pessoa de \& FIORIN, José Luiz (orgs.). Dialogismo, polifonia, intertextualidade. São Paulo: EDUSP, 1999 (p. 11-27).

BARTHES, Roland. A retórica da imagem. In: BARTHES, R. 1984. O óbvio e o obtuso: ensaios críticos III. Lisboa: Edições 70, 1964. (p. 27-37).

BERTRAND, Denis. L'espace et le sens. Paris-Amsterdam: Hadès/Benjamin, 1985.

CYPRIANO, Fabio. Pina Bausch. Imagem: Maarten Vanden Abeele. São Paulo: Cosac Naify, 2005.

_. Pina Bausch ergue sua Babel. In: Revista Bravo!, n 13. São Paulo, 1998, p. 129.

FIORIN, José Luiz. Elementos de análise do discurso. 14ª ed. São Paulo: Contexto 2006.

FLOCH, Jean-Marie. Petites Mythologies de l'oeil e de l'espirit - pour une semiothique plastique. Paris-Amsterdam: Hadès-Benjamin, 1985.

FONTANILLE, Jacques. Significação e visualidade: exercícios práticos. Porto Alegre: Sulina, 2006.

GREIMAS, Algirdas Julien. Sobre o sentido. Ensaios semióticos. Petrópolis: Vozes, 1975.

. Semiótica figurativa e semiótica plástica. In: Significação, Araraquara-SP: Centro de Estudos Semióticos, vol. 4, 1984 (p. 18-46).

Da Imperfeição. São Paulo: Hacker Editores, 2002.

GREIMAS Algirdas Julien \& COURTÉS, Joseph. Dicionário de semiótica. São Paulo: Cultrix, 1979.

HALL, Stuart. Codificação/Decodificação. In: culturais: Belo Horizonte: Ed. UFMG, 2003 (p. 387-406).

JAKOBSON, Roman. Lingüística e comunicação. Trad. De Izidoro Blikstein e José Paulo Paes. São Paulo: Cultrix, 1969.

KRISTEVA, Julia. Introdução à semanálise. São Paulo: Perspectiva, 1974.

JOLY, Martine. Introdução à análise da imagem. Campinas: Papirus. $6^{\text {a }}$ ed., 2003. 
NASCIMENTO, Geraldo Carlos do. A comunicação nas ciências da linguagem. In: Significação - Revista Brasileira de Semiótica. São Paulo: Annablume. Jul - no 17, 2002 (p. $59-75)$

OLIVEIRA, Ana Claudia. (org.). Semiótica plástica. São Paulo: Hacker Editores, 2004.

PIGNATARI, Décio. Informação, linguagem, comunicação. São Paulo: Ateliê Editorial, 2002.

PINA. Direção de Wim Wenders. Alemanha-França-Reino Unido, 2011. 1 filme (106 min.): son.; color.; suporte DVD.

ROCHA, Thereza. O corpo na cena de Pina Bausch. In: ANTUNES, A. (org.). Lições de dança 2. UniverCidade, 2000 (p. 143-174).

SERVOS, Norbert. Pina Bausch Wuppertal dance Theater or the art of training a goldfish. Colônia: Rolf Garske, 1984.

SCHMIDT, Jochen. Tanztheater in Deutschland. Frankfurt: Propyläen, 1992.

VOGEL, Walter. Pina. Munique: Quadriga, 2000.

ZILBERBERG, Claude. Raison et poétique du sens. Paris: PUF, 1988.

De l’afect à la valeur. In: CASTELLANA, Marcello (org.). Texte et valeur. Paris/Turim/Budapeste: L`Harmattan, 2001.

Original recebido em: 08/03/2013

Aceito para publicação em: 18/02/2016

Cristiane do Rocio Wosniak

Doutora em Comunicação e Linguagens (linha: Estudos de Cinema e Audiovisual) pela

Universidade Tuiuti do Paraná. Mestra pelo mesmo programa (linha: Cibermídia e Meios Digitais). Especialista em Artes pela FAP. Graduada em Ciências Biológicas (UFPR) e Dança

(PUC-PR). Professora Adjunta na Universidade Estadual do Paraná - campus Curitiba II/Faculdade de Artes do Paraná. É líder do GP CINECRIARE - Cinema: criação e reflexão

(UNESPAR/CNPq) e GRUDES - Desdobramentos Simbólicos do Espaço em Narrativas Audiovisuais (UTP/CNPq). É coreógrafa da Téssera Companhia de Dança da UFPR.

Esta obra está licenciada sob uma Licença Creative Commons. 